\title{
Growth of a Wild Strain and of a Pimelic Acid-utilizing Mutant of Pseudomonas azelaica on Aliphatic Dicarboxylic Acids
}

\author{
By L. JANOTA-BASSALIK* AND B. BOHDANOWICZ-STRUCINSKA \\ Institute of Microbiology, University of Warsaw, o0-046 Warszawa, Poland
}

(Received 18 January 1974; revised 5 April 1974)

\begin{abstract}
SUMMARY
Aliphatic dicarboxylic acids, homologous series $\mathrm{C}_{4}$ to $\mathrm{C}_{10}$ (except pimelic acid, $\mathrm{C}_{7}$ ), were utilized as sole carbon and energy sources by Pseudomonas azelaica, wild strain. A spontaneous Ps. azelaica $\mathrm{Pma}^{+}$mutant, able to utilize pimelic acid, was isolated from the wild strain on pimelate agar medium. Utilization of pimelic acid was the only character that differentiated the wild strain from the mutant. Experiments with Tween 80 showed that the ability to utilize pimelic and suberic acids by both strains of Ps. azelaica depended on cell permeability. These results suggest that the aliphatic dicarboxylic acids are metabolized by inducible enzymes and that the induction is not specific.
\end{abstract}

\section{INTRODUCTION}

Long-chain aliphatic dicarboxylic acids are formed when micro-organisms use aliphatic and aromatic hydrocarbons as carbon sources. A bacterial strain able to utilize azelaic acid, a 9-carbon dicarboxylic acid, as the sole source of carbon and energy was isolated and described by Janota-Bassalik \& Wright (1964a).

The strain decomposing azelaic acid was classified as a Pseudomonas species. On the basis of more careful characterization (Janota-Bassalik, Bohdanowicz-Strucińska \& Noras, I97I) it was found to differ from the described species and the name Pseudomonas azelaica was proposed.

Previous studies on azelaic acid degradation by micro-organisms have indicated that beta-oxidation is important in the reaction. Pimelic acid was found in the cultures of Pseudomonas sp., Micrococcus sp., and Moraxella lwoffi growing on azelate by JanotaBassalik \& Wright (I964b), Koichi, Tochikura, Osugi \& Ivahara (I966) and Chapman \& Duggleby (1967).

In this paper we investigate the degradation of different dicarboxylic acids by $P$ s. azelaica and by its mutant, Ps. azelaica $\mathrm{Pma}^{+}$.

\section{METHODS}

Organisms. Pseudomonas azelaica ATCC27I62, wild strain and its mutant, Ps. azelaica $\mathrm{Pma}^{+}$, were used, both strains being transferred every week. Pseudomonas azelaica was grown on nutrient agar and $P$ s. azelaica $\mathrm{Pma}^{+}$on pimelate agar.

Solutions. Salts solution A (g/l distilled water): $\left(\mathrm{NH}_{4}\right)_{2} \mathrm{SO}_{4}, \mathrm{I} \cdot 0 ; \mathrm{K}_{2} \mathrm{HPO}_{4}, 0.5$; $\mathrm{MgSO}_{4} \cdot 7 \mathrm{H}_{2} \mathrm{O}, 0 \cdot \mathrm{I} ; \mathrm{NaCl}, 0 . \mathrm{I}$. Salts solution $\mathrm{A}^{\prime}$ contained $\mathrm{K}_{2} \mathrm{HPO}_{4}$, $12.6 \mathrm{~g}$, and $\mathrm{KH}_{2} \mathrm{PO}_{4}$, $4.0 \mathrm{~g}$, per 1 salts solution A. Vitamins solution $(\mathrm{mg} / \mathrm{I} 00 \mathrm{ml}$ distilled water): thiamine hydrochloride, I0.0; calcium panthothenate, 10.0; riboflavin, 10.0; nicotinic acid, 10.0;

* Present address: The Polish Academy of Sciences, Institute of Genetics and Animal Breeding, Jastrzębiec 05-55I, Mroków, Poland. 
p-aminobenzoic acid, 10.0; inositol, 5.0; pyridoxal hydrochloride, I00; folic acid, 10.0; biotin, 0.08 .

Media. Unbuffered media: salts solution A, I 1, plus azelaic acid or pimelic acid, $3 \cdot 0 \mathrm{~g}$. Unbuffered media with pimelic acid additionally contained I $\mathrm{ml}$ of vitamins solution, or - I g of azelaic acid, glutaric acid, alpha-ketoglutaric acid or vitamin-free casein hydrolysate. Buffered media: salts solution $A^{\prime}, I$, plus sufficient dicarboxylic acid $\left(C_{2}\right.$ to $\left.C_{10}\right)$, acetic acid or glucose to give 0.14 moles of organic carbon. Unbuffered and buffered media were sterilized at $\mathrm{I}_{2 \mathrm{I}}{ }^{\circ} \mathrm{C}$ for $20 \mathrm{~min}$. Each litre of media was then enriched with I $\mathrm{ml}$ of filtersterilized $2 \% \mathrm{FeSO}_{4} \cdot 7 \mathrm{H}_{2} \mathrm{O}$ solution, and the $\mathrm{pH}$ was adjusted to 6.9 to $7 \cdot 1$ with $\mathrm{NaOH}$ solution.

Pimelate agar: unbuffered pimelate liquid medium solidified with $\mathrm{I} \cdot 8 \%$ Difco agar. Media for the identification of Ps. azelaica $\mathrm{Pma}^{+}$were prepared according to Janota-Bassalik \& Wright (1964a).

Culture. Liquid unbuffered medium with azelaic acid was inoculated with cells from $24 \mathrm{~h}$ cultures on nutrient agar. Exponentially growing liquid cultures $(0 \cdot \mathrm{I} \%, \mathrm{v} / \mathrm{v})$ were used as inocula for experimental media. The cultures were incubated at $28{ }^{\circ} \mathrm{C}$ on a rotary shaker at I 80 strokes/min.

Respiration of cultures was routinely determined by the Warburg method at $28^{\circ} \mathrm{C}$.

Determination of dicarboxylic acids. The content of dicarboxylic acids in the cultures of both pseudomonad strains was determined after different periods of growth. Samples of the cultures, acidified to $\mathrm{pH} \mathrm{I} \cdot 0$ with concentrated $\mathrm{H}_{2} \mathrm{SO}_{4}$, were extracted with diethyl ether and the extracts shaken with $5 \% \mathrm{NH}_{4} \mathrm{OH}$. Then, either the water phase was separated and used for paper chromatography, or the extracts were evaporated, dried over $\mathrm{P}_{2} \mathrm{O}_{5}$, and the acids converted into methyl esters by the method of Szczepańska \& Beldowicz (1969) to be examined by gas chromatography. Ascending chromatography on Whatman No. I filter paper with the solvent system $25 \%$ ethanol: ammonia: water (I00: 16: 12, by vol.) of Bolliger et al. (1962), and gas chromatography using a Pye chromatograph with a beta ionizing detector were used. A glass column $1200 \mathrm{~mm}$ long and $4 \mathrm{~mm}$ in diameter was used for gas chromatography and was packed with $6 \%$ SE-30 (liquid phase) in relation to solid carrier (Gas-chrom 60-80). The carrier gas was argon, the flow rate $100 \mathrm{ml} / \mathrm{min}$, the temperature of the column $120^{\circ} \mathrm{C}$, and the volume of the examined samples 90 to $100 \mathrm{~mm}^{3}$. Methyl esters of pure dicarboxylic acids were used as standards and had the same retention time as the products identified.

\section{RESULTS}

\section{Isolation of Pseudomonas azelaica Pma ${ }^{+}$}

Pseudomonas azelaica did not grow on pimelate alone, on pimelate enriched with small amounts of easily utilizable acids, or on pimelate with casein hydrolysate or vitamins. However, we observed significantly greater turbidity in cultures grown on $0.01 \%$ azelate with $0.3 \%$ pimelate than on controls with $0.01 \%$ azelate alone, suggesting that some cells of Ps. azelaica had acquired the ability to utilize pimelic acid. This was confirmed by the isolation of clones utilizing pimelic acid from colonies grown on pimelate agar inoculated with a dense suspension of Ps. azelaica wild strain. One spontaneously produced mutant named Ps. azelaica $\mathrm{Pma}^{+}$was shown to be identical with $P$ s. azelaica, except in its response to pimelic acid. The ability of $P$ s. azelaica $\mathrm{Pma}^{+}$to utilize azelaic acid after several transfers on eurrdlic acid was less than that of the parent strain. 
Growth of Ps. azelaica and of Ps. azelaica Pma ${ }^{+}$on buffered media with dicarboxylic acids $\left(C_{2}\right.$ to $\left.C_{10}\right)$

Media were inoculated with equal numbers of bacteria. The best growth, for both strains, was obtained on succinate $\left(\mathrm{C}_{4}\right)$, glutarate $\left(\mathrm{C}_{5}\right)$ and adipate $\left(\mathrm{C}_{6}\right)$. The rate of growth and the maximum turbidity of cultures grown on all of these acids were similar. The exponential phase of growth was preceded by a moderate lag phase. Both strains grew well on azelate $\left(\mathrm{C}_{9}\right)$ and on sebacate $\left(\mathrm{C}_{10}\right)$ after a $\mathrm{I}_{4} \mathrm{~h}$ lag phase. Suberic acid $\left(\mathrm{C}_{8}\right)$ was utilized after a long lag phase, lasting from 24 to $40 \mathrm{~h}$, and not all cultures grew exponentially. Only Ps. azelaica $\mathrm{Pma}^{+}$grew on pimelic acid $\left(\mathrm{C}_{7}\right)$, and only after a $23 \mathrm{~h}$ lag phase. Neither strain grew on oxalate or malonate.

Influence of the carbon source used to grow the inocula on the subsequent growth rate of Ps. azelaica and of Ps. azelaica Pma ${ }^{+}$

Cultures grown on glucose, adipate, azelate and sebacate were used in $0.1 \%$ volume to inoculate media containing glucose or one of the dicarboxylic acids, adipate, azelate or sebacate. In addition, for experiments with Ps. azelaica $\mathrm{Pma}^{+}$, pimelate medium was inoculated with cultures grown on pimelate.

Growth on dicarboxylic acid media did not depend on the dicarboxylic acid substrate used to grow the inocula. Growth on glucose, however, depended on the substrate; both strains grew on glucose without evident lag phase when the inoculum was grown on glucose, but when it was grown on a dicarboxylic acid medium, the lag phases on glucose were 16 to I $8 \mathrm{~h}$. It would seem that the degradation of glucose by both strains of Ps. azelaica depends on the induction of the enzymes active in that process.

Influence of Tween 80 on the growth of Ps. azelaica on suberate, pimelate and azelate

Bacteria were grown on buffered media containing $0.1 \%$ Tween 80 and suberate, pimelate or azelate. Media containing no Tween 80 and media containing Tween 80 as the only carbon source were used as controls.

Pseudomonas azelaica did not grow when Tween 80 was the sole carbon source. Tween 80 did not influence the growth of $P$ s. azelaica on azelate, but stimulated growth on suberate. In the presence of Tween 80 slight growth of $P$ s. azelaica on pimelate was noted (Fig. I).

Influence of acrylic acid on the respiratory activity of Ps. azelaica and Ps. azelaica Pma ${ }^{+}$

Acrylic acid, a specific inhibitor of beta-oxidation (Thijsse, 1964), reduced the oxygen uptake by both strains of $P$ s. azelaica when dicarboxylic acids were used as oxidation substrates. Under the influence of $\mathrm{I} 4 \mathrm{nmol}$ acrylic acid in the reaction mixture, oxygen uptake by the wild strain, measured after $3 \mathrm{~h}$, was reduced by 55,60 and $53 \%$ in the presence of adipate, azelate, and sebacate respectively. Under the same conditions, oxygen uptake by the $\mathrm{Pma}^{+}$mutant was reduced by $47,40,42$ and $30 \%$ in the presence of adipate, pimelate, azelate, and sebacate, respectively. Acrylic acid did not influence oxygen uptake by either strain when acetic acid was used as oxidation substrate, or in endogenous respiration (Table I). 


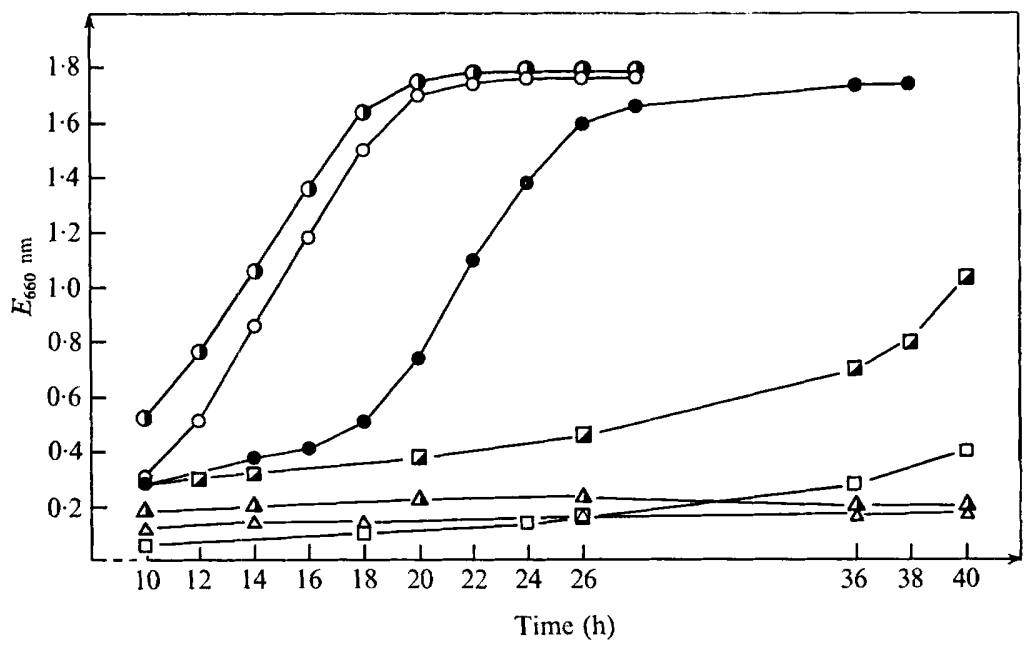

Fig. I. Growth of Pseudomonas azelaica in liquid media with $0.3 \%$ dicarboxylic acids \pm Tween 80 , or Tween 80 alone. $\Delta$, Pimelic acid; $\square$, pimelic acid + Tween $80 ; \square$, suberic acid; 0 , suberic acid +Tween 80; $O$, azelaic acid; $O$, azelaic acid + Tween $80 ; \triangle$, Tween 80.

Table I. Influence of acrylic acid on substrate respiration by resting suspensions of Ps. azelaica and Ps. azelaica Pma ${ }^{+}$

\begin{tabular}{|c|c|c|}
\hline \multirow[b]{2}{*}{ Substrate } & \multicolumn{2}{|c|}{$\begin{array}{c}\text { Oxygen uptake } \\
(\mu \mathrm{l} / \mathrm{mg} \text { dry wt } / \mathrm{I} 80 \mathrm{~min})\end{array}$} \\
\hline & $\begin{array}{l}\text { Pseudomonas } \\
\text { azelaica }\end{array}$ & $\begin{array}{l}\text { Pseudomonas } \\
\text { azelaica } \text { Pma }^{+}\end{array}$ \\
\hline Endogenous respiration & I 5.56 & $16 \cdot 76$ \\
\hline $\begin{array}{l}\text { Endogenous respiration }+ \\
\text { acrylic acid }\end{array}$ & 20.01 & 19.05 \\
\hline Acetic acid & $130 \cdot 10$ & $\mathrm{I} 26 \cdot 4 \mathrm{I}$ \\
\hline Acetic acid + acrylic acid & 128.85 & $121 \cdot 98$ \\
\hline Adipic acid & $132 \cdot 98$ & 125.96 \\
\hline Adipic acid + acrylic acid & 60.07 & 67.07 \\
\hline Pimelic acid & - & $157 \cdot 50$ \\
\hline Pimelic acid + acrylic acid & - & $92 \cdot 34$ \\
\hline Azelaic acid & $180 \cdot 00$ & $74 \cdot 25$ \\
\hline Azelaic acid + acrylic acid & $73 \cdot 43$ & $43 \cdot 10$ \\
\hline Sebacic acid & $212 \cdot 15$ & $66 \cdot 34$ \\
\hline Sebacic acid + acrylic acid & $100 \cdot 3 \mathrm{I}$ & $4 I \cdot 06$ \\
\hline
\end{tabular}

The main Warburg vessels, agitated at the rate of 140 strokes/min with a $2.5 \mathrm{~cm}$ span, contained, per 2.0 $\mathrm{ml}$ : $100 \mathrm{nmol}$ phosphate buffer, $\mathrm{pH} 7 \cdot 0$; bacterial cell suspension equivalent to $1 \cdot 2 \mathrm{mg}$ dry $\mathrm{wt}$; $14 \mathrm{nmol}$ acrylic acid; and substrate equivalent to $27 \mathrm{nmol}$ organic carbon. Acrylic acid was added to the main vessel from the side-arm after $30 \mathrm{~min}$. Mixtures without acrylic acid served as controls.

\section{Products of dicarboxylic acid degradation by Ps. azelaica and by}

Ps. azelaica Pma ${ }^{+}$

Suberic acid was repeatedly detected by paper chromatography in the cultures of both $P$ s. azelaica strains growing on sebacic acid. In cultures of Ps. azelaica, wild strain, growing exponentially on azelaic acid, azelaic, suberic, pimelic, glutaric and succinic acids were found by gas chromatography; the amount of pimelic acid, the carbon 
compound not used by this strain, increased during the stationary growth phase. In cultures of Ps. azelaica $\mathrm{Pma}^{+}$grown on azelaic acid, only suberic acid was detected during logarithmic and stationary growth phases. Trace amounts of adipic, glutaric and succinic acids were present in cultures of $P$ s. azelaica $\mathrm{Pma}^{+}$growing on pimelic acid.

\section{DISCUSSION}

Some dicarboxylic acids are not used as growth substrates by Pseudomonas azelaica. The most interesting in this respect is pimelic acid, a by-product of azelaic acid degradation. Similar observations were made by Koichi et al. (1966) on another bacterium which utilized azelaic acid, Micrococcus AI33. The isolation and characteristics of Ps. azelaica $\mathrm{Pma}^{+}$indicate that the ability to decompose pimelic acid may be acquired by mutation. Other mutants are known which differ from their parent strain in ability to utilize some monocarboxylic acids. For example, ability to grow on butyric and valeric acids was observed for a mutant of Escherichia coli KI2 (Vandervinkel, Furmanski, Reeves \& Ajl, 1968), and ability to grow on capric (decanoic) acid was observed for a mutant of $E$. coli SR258 (Weeks, Shapiro, Burns \& Wakil, 1969), although neither parent strain used these substrates. Weeks and his coworkers suggested that induction of the $E$. coli enzymes which degrade carboxylic acids occurred. This hypothesis was based on observations on the length of the lag phase preceding the growth of $E$. coli on media containing carboxylic acids. Hoet \& Stanier (1970) showed that the enzymes of Pseudomonas fuorescens which decompose long-chain aliphatic dicarboxylic acids are inducible and that this induction is not specific for a given acid. The fact that the lengths of the lag phases of both strains of $P$ s. azelaica grown on dicarboxylic acids were independent of the kind of acid used to grow the inocula suggests the same conclusion. Our experiments with Tween 80 indicate that the induction of the enzymes metabolizing dicarboxylic acids might be observed under conditions which facilitate the entry of substrates into the cells.

Hoet \& Stanier (I970) suggested that the oxidation by Ps. fluorescens of the dicarboxylic acids having an odd number of carbon atoms needs the synthesis of the enzymes of alphaoxidation. According to these authors, Ps. fluorescens synthesizes the enzymes of betaoxidation during the degradation of dicarboxylic acids having an even number of carbon atoms.

We have confirmed the accumulation of suberic acid in cultures of Ps. azelaica and Ps. azelaica $\mathrm{Pma}^{+}$growing on sebacic acid and the accumulation of pimelic acid in the culture of $P$ s. azelaica growing on azelaic acid, reported by Janota-Bassalik \& Wright (1964b). These results indicate that beta-oxidation is the mechanism active during the degradation of dicarboxylic acids, independent of the number of carbon atoms in the chains. The accumulation of suberic acid in cultures of Ps. azelaica and Ps. azelaica Pma ${ }^{+}$growing on azelaic acid, and the accumulation of traces of adipic acid in the culture of Ps. azelaica $\mathrm{Pma}^{+}$growing on pimelic acid, indicate that alpha-oxidation is a parallel reaction to betaoxidation in the degradation process. 


\section{REFERENCES}

Bolliger, H. R., Bremer, M., Gänshirt, H., Mangold, H. K., Seiler, H., Stahl, E. \& Waldi, O. (1962). In Dünnschicht-Chromatographie; ein Laboratoriumshandbuch, p. 369. Berlin, Göttingen and Heidelberg: Springer Verlag.

Chapman, P. J. \& DugGleby, R. G. (1967). Dicarboxylic acid catabolism by bacteria. Biochemical Journal I30, $7 \mathrm{c}-9 \mathrm{c}$.

Hoet, P. P. \& Stanier, R. Y. (1970). The dissimilation of higher dicarboxylic acids by Pseudomonas fluorescens. European Journal of Biochemistry 13, 65-70.

Janota-BASSAlik, L., BohDANowicz-StruciŃsKa, B. \& Noras, A. (I97I). Observations on Pseudomonas sp. highly tolerant to creosote, isolated from railway wood sleepers. Acta microbiologica polonica B 3 , I43-I 53.

JANota-Bassalik, L. \& Wright, L. D. (I964a). Azelaic acid utilization by a Pseudomonas. Journal of General Microbiology 36, 405-414.

Janota-Bassalik, L. \& WRIGHT, L. D. (1964b). Pimelic acid as a by-product of azelaic acid degradation by Pseudomonas sp. Nature, London 204, 50I-502.

Koich, O., Tochikura, T., Osugi, M. \& Ivahara, I. (I966). Fatty acid metabolisms in microorganisms. Production of pimelic acid from azelaic acid. Agricultural and Biological Chemistry, Tokyo 30, 176-179.

SzCZEPańSKA, H. \& BezDowicz, M. (1969). Conversion of fatty acids into methyl esters for analytical purposes. Tluszcze, Srodki Piorace, Kosmetyki 13 S (in Polish).

THussSE, G. J. E. (1964). Fatty acid accumulation by acrylate inhibition of $\beta$-oxidation in alkane oxidizing Pseudomonas. Biochimica et biophysica acta 84, 195-197.

Vandervinkel, E., Furmanski. P., Reeves, H. C. \& Ajl, S. J. (I968). Growth of E. coli on fatty acids. Requirement for coenzyme A transferase activity. Biochemical and Biophysical Research Communications 33, 902-908.

Weeks, G., Shapiro, M., Burns, R. O. \& Wakit, S. J. (I969). Control of fatty acid metabolism. I. Induction of the enzymes of fatty acid oxidation in Escherichia coli. Journal of Bacteriology 97, 827-836. 